\title{
Gene cloning and transformation of Arabidopsis plant to study the functions of the Early Responsive to Dehydration gene (ERD4) in coffee genome
}

\author{
- Nguyen Dinh Sy \\ Institute of Environment and Biotechnology, Taynguyen University \\ - Hunseung Kang \\ College of Agriculture and Life Sciences, Chonnam National University
}

(Received on $23^{\text {th }}$ November 2015, accepted on May $5^{\text {th }}$ 2016)

\begin{abstract}
Coffee plant is one of the most important industrial crops, and the two popular cultivars, Coffea arabica and Coffea canephora, contribute to the production of almost all coffee beans around the world. Although the demand for coffee beans is continually increasing, the steady production of coffee beans is hampered by many factors, such as environmental stresses, insect pests, and diseases. Traditional breeding could be used to develop new coffee cultivars with a higher productivity under these harsh conditions, and a biotechnological approach can also be used to improve coffee plants in a relatively short
\end{abstract} period of time. To develop new coffee cultivars via a biotechnological approach, it is necessary to discover potential candidate genes and determine their functions in coffee plants. However, it is technically difficult to introduce foreign genes into coffee genome and takes long time to analyze gene function in coffee plants. To overcome these technical difficulties, the potential coffee genes could be cloned and introduced into Arabidopsis for the rapid analysis of its biological functions under harsh environmental conditions.

Keywords: Arabidopsis, Coffee genome, gene cloning, transgenic plant

\section{INTRODUCTION}

Coffee plant is a tropical crop belonging to Rubiaceae family that has more than 100 species which are native of African continent, Madagascar, and the Mascarene Islands [1]. Although many varieties of coffee cultivars exist, most of the coffee beverages are made from two species, Arabica coffee (Coffea Arabica) and Robusta coffee (Coffea canephora), with export values of approximately US\$22 billion in the year of 2012 and over 600 billion cups consumed every year throughout the world [2]. Coffee plants are currently cultivated in 80 countries producing approximately $70 \%$ and $30 \%$ of Arabica and Robusta beans, respectively [3]. A report by ICO (International Coffee Organization) indicated that ten leading countries, including Brazil, Vietnam, Indonesia, Colombia, Ethiopia, India, Honduras, Peru, Mexico, and Guatemala, contribute $35 \%, 15.2$ $\%, 8.8 \%, 7.1 \%, 4.4 \%, 3.7 \%, 3.1 \%, 3.1 \%, 3.0$ $\%$, and $2.6 \%$ of world coffee bean production, respectively [2]. 
C. canephora is the diploid species $(2 n=22$ chromosomes) and is self-incompatible, whereas C. arabica is allotetraploid $(2 \mathrm{n}=4 \mathrm{x}=44$ chromosomes) self-fertile species [4] that was originated from cross between $C$. eugenoides and C. canephora [5]. Due to the differences in morphological and physiological characteristics, C. canephora appears to be more vigorous, productive, and resistant to disadvantageous conditions than $C$. Arabica does [6]. In general, $C$. Arabica is preferred to $C$. canephora due to its low-caffeine content and less-bitter taste.

In recent years, global warming causes severe climate changes, including high and low temperatures, prolonged-drought season, or alteration of raining and snowing patterns, that significantly affects the yield of agricultural products. The productivity of coffee plants can be reduced up to $80 \%$ by environmental stresses, including drought, salt, cold, high temperature, and UV light, especially by prolonged water deficiency [6]. Until now, conventional breeding has mainly been used to improve coffee plants, but it takes a long time (approximately 30 years) and requires many steps, including selection, hybridization, and progeny evaluation, to develop a new coffee cultivar via conventional breeding. Therefore, in other to develop a new coffee cultivar that has beneficial traits such as abiotic and biotic stress tolerance, disease resistance, or quality and quantity improvement, more rapid and efficient strategy utilizing genetic transformation technology is required.

During the last two decades, genetic researches on coffee plants demonstrated the regulation, function, and interactions of coffee genes. Several research groups analyzed the coffee transcriptomes and expressed sequence tags (ESTs) from both Robusta and Arabica coffee plants [7-8], and other groups utilized oligo-based microarray containing 15,721 unigenes to study the functions of coffee genes involved in bean maturation or resistance to pathogens or drought [9], which opens a way for functional genomics of coffee plants. The EST sequences of $C$. arabica can be found at the public website (http://www.coffee.dna.net) [10], and the genome assembly and gene models of $C$. canephora are available on the Coffee Genome Hub (http://coffee-genome.org) [11]. In addition, transformation systems of coffee plants, utilizing electroporation [12], microprojectile bombardment [13-17], Agrobacterium tumefaciens [18-26], or A. rhizozenes [27-31], have been developed to deliver potential target genes into coffee plants. However, it takes long time and is technically difficult to introduce foreign genes into coffee genome due to low percentage of successful transformation, which significantly restrains the functional analysis of potential genes in coffee plants.

To overcome these technical difficulties, more rapid and efficient system is required to analyze the functions of coffee genes in a reasonable time periods. Here, we introduce an efficient system using a model plant Arabidopsis thaliana to investigate the functions of coffee genome, which is practical, less time- and laborconsuming, and can be utilized in many laboratories in Vietnam.

\section{MATERIALS AND METHODS}

\section{C. canephora}

The Robusta coffee plant (C. canephora) was used in this experiment. The exocarp layer of coffee beans was removed, and the seeds were placed into warm water $\left(60^{\circ} \mathrm{C}\right)$ for 24 hours and laid on humid paper at $30{ }^{\circ} \mathrm{C}$ until radical root development. The germinated seeds were sown on peat moss in circle pots and then were grown in the growth room maintained at $23 \pm 2{ }^{\circ} \mathrm{C}$ under long-day conditions (16-h light/8-h dark cycle) with the light intensity of approximately $100 \mu \mathrm{E}$

\section{Trang 54}


$\mathrm{m}^{-2} \mathrm{sec}^{-1}$. The plants were watered twice per week.

\section{A. thaliana}

The Col- 0 ecotype of $A$. thaliana was used in this experiment. Seeds were sown on a $3: 1: 1$ mixture of peat moss, vermiculite, and perlite in circle pots, and then placed at $4{ }^{\circ} \mathrm{C}$ for 3 days in the dark for stratification. The pots were transferred to the growth room maintained at $23 \pm 2{ }^{\circ} \mathrm{C}$ under long-day conditions (16-h light/8$\mathrm{h}$ dark cycle) with the light intensity of approximately $100 \mu \mathrm{E} \mathrm{m}^{-2} \mathrm{sec}^{-1}$. The plants were watered twice per week.

\section{Total RNA extraction and cDNA synthesis}

The leaf tissues of 4-month-old coffee plants were ground under liquid nitrogen using a mortar and pestle, and total RNA was extracted using a GeneAll kit (GeneAll Biotechnology Co., Ltd., Korea). The purity and concentration of total RNA were accurately determined by spectrophotometric measurement using a NanoDrop US/ND-1000 spectrophotometer (Qiagen, USA). The complementary DNA (cDNA) was synthesized from $5 \mu \mathrm{g}$ of total RNA using the reverse transcriptase and oligo dT primers (Promega, USA).

\section{Identification and isolation of coffee genes}

The full genome sequences of $C$. canephora are found at the website (http://coffeegenome.org). The nucleotide sequences of ERD (early responsive to dehydration) family genes were downloaded from the database and utilized as a template to design the primers for cloning the genes. The coding regions of ERD genes were amplified by polymerase chain reaction (PCR) using the cDNA as a template and the primers specific to each gene, and the resulting PCR products were ligated into the pGEM T-easy vector (Promega, USA). The amplification and sequence of target genes was verified by DNA sequencing.
Vector construction and plant transformation

The pGEM T-easy vector containing ERD gene was digested with $\mathrm{XbaI}$ and SacI, and the resulting DNA was then sub-cloned into the pBI121 vector that was linearized by a double digestion with the same restriction enzymes. All DNA manipulations were according to standard protocols [32], and the ERD coding region and the junction sequences were confirmed by DNA sequencing. Transformation of Arabidopsis was carried out according to the vacuum infiltration method [33] using Agrobacterium tumefaciens GV3101. Seeds were harvested and plated on the selection medium containing kanamycin (50 $\left.\mu \mathrm{g} . \mathrm{mL}^{-1}\right)$ and carbenicillin $\left(250 \mu \mathrm{g} \cdot \mathrm{mL}^{-1}\right)$ to identify transgenic plants.

\section{RESULTS AND DISCUSSIONS}

Analysis of coffee genome, selection of candidate gene and primer design

The $C$. canephora genome harbors 25,574 protein-coding genes, which are found online at the website (http://coffee-genome.org) and can be downloaded to find the information of any genes of interest. In this study, we aimed to identify and study the ERD gene family, because they are known to be involved in drought stress response in plants. Using the ERD as a search keyword to identify the ERD family genes, we found $20 \mathrm{ERD}$ genes in the $C$. canephora genome. Among the 20 predicted ERD genes, the ERD4 (accession no. Cc10_g07790) was selected (Table 1) for cloning and analyzing its function in Arabidopsis plant.

The full-length nucleotide sequence of ERD4 gene was analyzed using the Gene Runner software (http://gene-runner.software.informer. com) to locate the start and stop codons, and the forward and reverse primers were designed to amplify the gene (Table 1). The restriction enzyme sites, Xba1 and Sac1 for the forward and reverse primers, respectively, were added at the 
end of the primers for the cloning of the gene into the pBI121 vector at a later stage (Table 1). It should be noted that the restriction enzymes which do not cut the inside of the target gene should be used, and that the PCR primers are usually around 18-24 bp in length and less than 3 ${ }^{\circ} \mathrm{C}$ difference in the annealing temperature of forward and reverse primer pairs.

Table 1. Sequences of nucleotide, amino acid, and primer of ERD4 gene

\begin{tabular}{|c|c|}
\hline Gene name & Cc10_g07790: Early-responsive to dehydration stress protein4 (ERD4) \\
\hline $\begin{array}{l}\text { Nucleotide } \\
\text { sequence } \\
(2,235 \mathrm{bp})\end{array}$ &  \\
\hline $\begin{array}{c}\text { Amino acid } \\
\text { sequence } \\
\text { (744 aa) }\end{array}$ & $\begin{array}{l}\text { MYLAALLTSAGINIAVCVVIFSLYSILRKQPRFMNVYFGQKLAHAKSRRQDPFCFERLVPSASWIVKAWEASEDQI } \\
\text { CAAGGLDALVFIRLIVFSIRIFSIAATICISLVLPLNYYGHDMEHKVIPSESLEVFSIANVQKGSKRLWAHCLALYIISC } \\
\text { CTCALLYHEYKSITKLRLLHITEALSNPSHFTVLVRGIPSSQTESYSETVAKFFSTYYASSYLSHKMVYQSGTVQKL } \\
\text { MSDAGKMYKMLKTCTREQQCGPNLMRCGLCGGTTSSFKMLAIESQNDKGRSDFDAADLRRKECGAAFVFFRTR } \\
\text { YAALVAAQSLQSQNPMKWVTERAPDPKDVYWTNLGLPYRILWIRRIAIFVVSILFVAFFLVPVTLTQSLVNLDKLQ } \\
\text { NTFPFLKGILKRKFMSQLATGYLPSVILMLFLYMAPPLMLFFSTMEGAVSRSGRKSACIKLLYFMIWNVFFANILT } \\
\text { GTIIKNLVGEVTRRLQDPKNIPNELATAIPTTATFFMTYILTSGWASLSFEILQPLALICNLFYRYALRNKDESTYGT } \\
\text { WTFPYHTEIPRVILFGVMGFTCSIMAPLILPFLLVYFFLAYLVYRNQILNVYVTKYQTGGLYWPTVHNATIFSLVLT } \\
\text { QIIASGVFGIKKSTVASSFTFPLIILTLLFNEYCRQRFLPVFKRNAAKVLIEMDWQDEQSGIMEETHQKLQSAYCQLT } \\
\text { LTTLHQDATLHEHPGETVASGLQDLENLDSGKTQTSGLWAGHSSPEIKELHAM }\end{array}$ \\
\hline $\begin{array}{c}\text { Primer } \\
\text { sequence }\end{array}$ & $\begin{array}{l}\text { TCTAGAATGTACTTAGCTGCTCTATTGAC (underline: Xba1 restriction enzyme site) } \\
\text { se: GAGCTCCTACATCGCATGAAGCTC (underline: Sac1 restriction enzyme site) }\end{array}$ \\
\hline
\end{tabular}

\section{Trang 56}




\section{Cloning and vector construction}

The cDNA encoding ERD4 gene was amplified by PCR using a TaKaRa Ex Taq DNA polymerase kit together with the cDNA of $C$. canephora and the gene-specific primers (Table 1). After 25-30 cycles of PCR reaction, $10 \times$ loading buffer $(2 \mu \mathrm{L})$ was added to the PCR reaction solution $(20 \mu \mathrm{L})$, and the mixture was loaded on $1 \%(\mathrm{~W} / \mathrm{V})$ agarose gel and subjected to gel electrophoresis at $100 \mathrm{~V}$ for $20 \mathrm{~min}$ in TAE (Tris-acetate-EDTA) buffer. After gel electrophoresis, the PCR products on the gel were visualized under UV light, and the DNA band of correct size (Fig. 1A) was eluted from the gel. The PCR product was ligated into the pGEM T-easy vector at $16^{\circ} \mathrm{C}$ for overnight, and the ligation product was transformed into the Escherichia coli XL blue competent cells. To confirm that correct gene was amplified by PCR, the colonies surviving on LB agar containing ampicillin (100 $\left.\mathrm{mg} \mathrm{mL}^{-1}\right)$ were subjected to PCR to determine whether the size of the amplified gene is identical to the ERD4 gene (Fig. 1B), and then the identity of the gene was confirmed by DNA sequencing. For sub-cloning the ERD4 gene into the pBI121 vector (C1), the pGEM Teasy plasmid containing the ERD4 gene as well as the pBI121 vector were double digested with the XbaI and SacI restriction enzymes at $37{ }^{\circ} \mathrm{C}$ for $4 \mathrm{~h}$. The cleavage products were visualized by gel electrophoresis on agarose gel (Fig. 1C), and the ERD4 gene and the linearized pBI121 vector were eluted and ligated together. The insertion of correct ERD4 into the pBI121 vector was confirmed by selection of the colony on LB agar containing kanamycin $\left(50 \mathrm{mg} \mathrm{mL}^{-1}\right)$, colony PCR (Fig. 1D), and DNA sequencing. To prepare the Agrobacterium for plant transformation, the pBI121 vector containing the ERD4 gene was transformed into the A. tumefaciens GV3101, the colonies grown on YEP medium containing kanamycin $\left(50 \mathrm{mg} \mathrm{mL}^{-1}\right)$ and rifampicin $(50 \mathrm{mg}$ $\mathrm{mL}^{-1}$ ) were selected, and the insertion of correct ERD4 gene was finally confirmed by colony PCR (Fig. 1E). Through these series of processes, we successfully cloned the coffee ERD4 gene into the pBI121 vector in A. tumefaciens GV3101, which is now ready for plant transformation. 
A PCR and pGEM T vector ligation

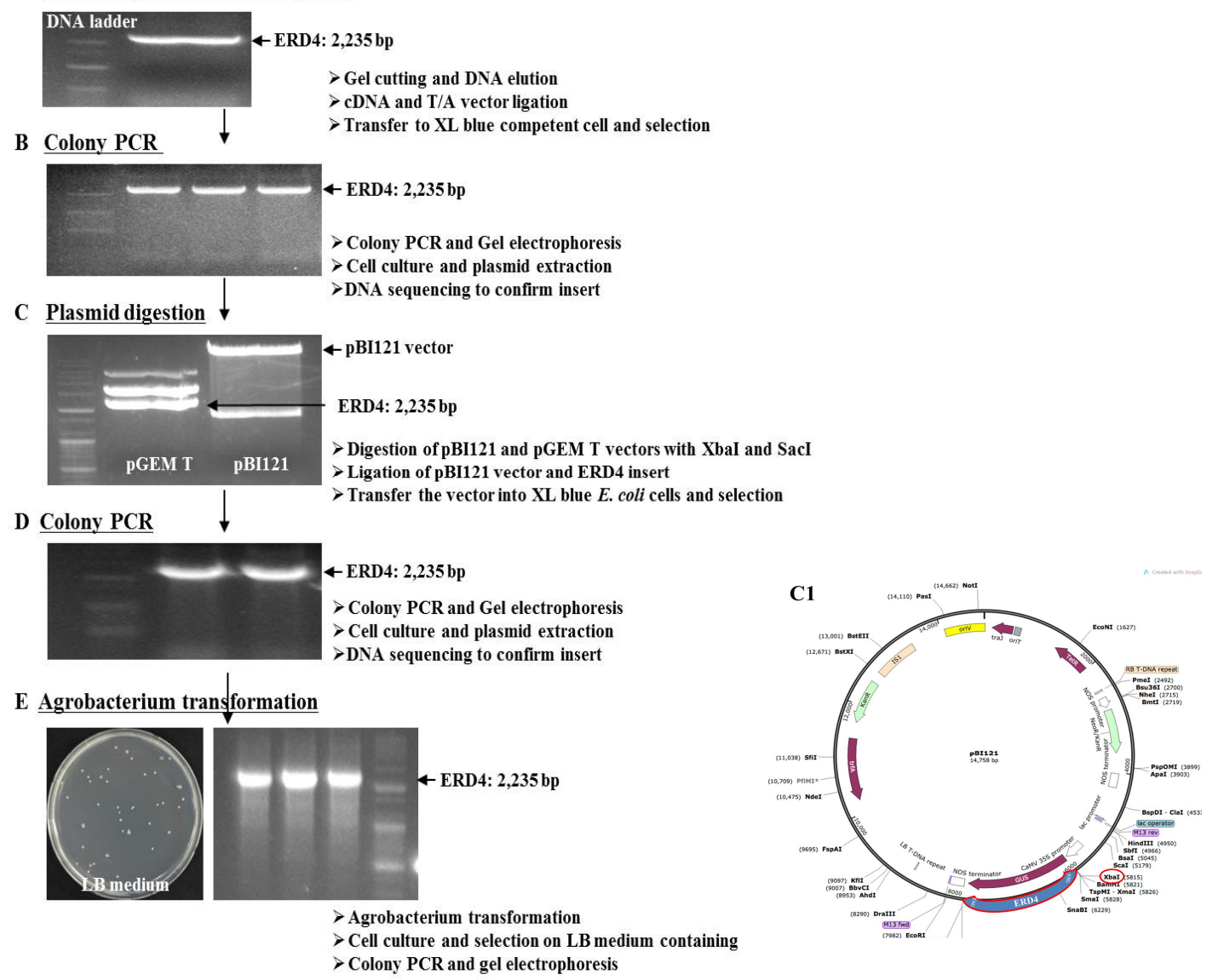

Fig. 1. Procedures for the cloning of $C$. canephora ERD4 gene. The cDNA encoding ERD4 gene was amplified and ligation into the pGEM T-easy vector (A, B). The pBI121 and pGEM T-easy vectors were digested with XbaI and SacI, the ERD4 gene was ligated into the pBI121 vector (C1), and the resulting vector was introduced into E. coli XL blue cells (C, D). The pBI121 vector harboring ERD4 gene was introduced into A. tumefaciens, and the colonies containing ERD4 gene were selected and confirmed by colony PCR (E).

\section{Plant transformation and homogeneous line selection}

Seven-week-old Arabidopsis plants in which all seeds and flowers, except buds, were removed (Fig. 2A) and were used for Agrobacteriummediated transformation according to the vacuum infiltration method (Fig. 2B); [33]. The pot containing Arabidopsis plants was put upsidedown in $600 \mathrm{~mL}$ of the Agrobacterium solution containing $1.32 \mathrm{~g}$ MS medium, $30 \mathrm{~g}$ sucrose, and $200 \mu \mathrm{L}$ silwet, and vacuum was applied for $5 \mathrm{~min}$ to facilitate infection (Fig. 2C). After infiltration, the plants were grown in normal growth room to harvest the seeds (Fig. 2D). The seeds were sown on MS medium containing kanamycin, and the transformants were selected; the seedlings of non-transformants turned yellow and showed abnormal growth compared with the transgenic lines (Fig. 2E). This transgenic lines are called $\mathrm{T}_{1}$ plants. The surviving $\mathrm{T}_{1}$ lines were grown in soil, the seeds were harvested, and the seeds were sown again on MS medium containing kanamycin. The seedlings should have a 3 survival: 1 un-survival ratio (Fig. 2F). These

\section{Trang 58}


transgenic lines are called $\mathrm{T}_{2}$ plants. The surviving $\mathrm{T}_{2}$ lines were grown in soil, and the seeds were harvested. All seeds survived on MS medium containing kanamycin (Fig. 2G), which is now called homogeneous $T_{3}$ plants. The $T_{3}$ homo lines were grown to amplify the seeds for functional assay (Fig. 2H). To confirm whether the ERD4 gene was successfully introduced into the $\mathrm{T}_{3}$ lines, RT-PCR was carried out with the primers specific to ERD4 gene. The result showed that strong bands corresponding to ERD4 gene were observed in all transgenic lines (Fig. 2I), confirming that coffee ERD4 gene was successfully introduced into Arabidopsis plants. These transgenic lines could be used for further functional analysis.

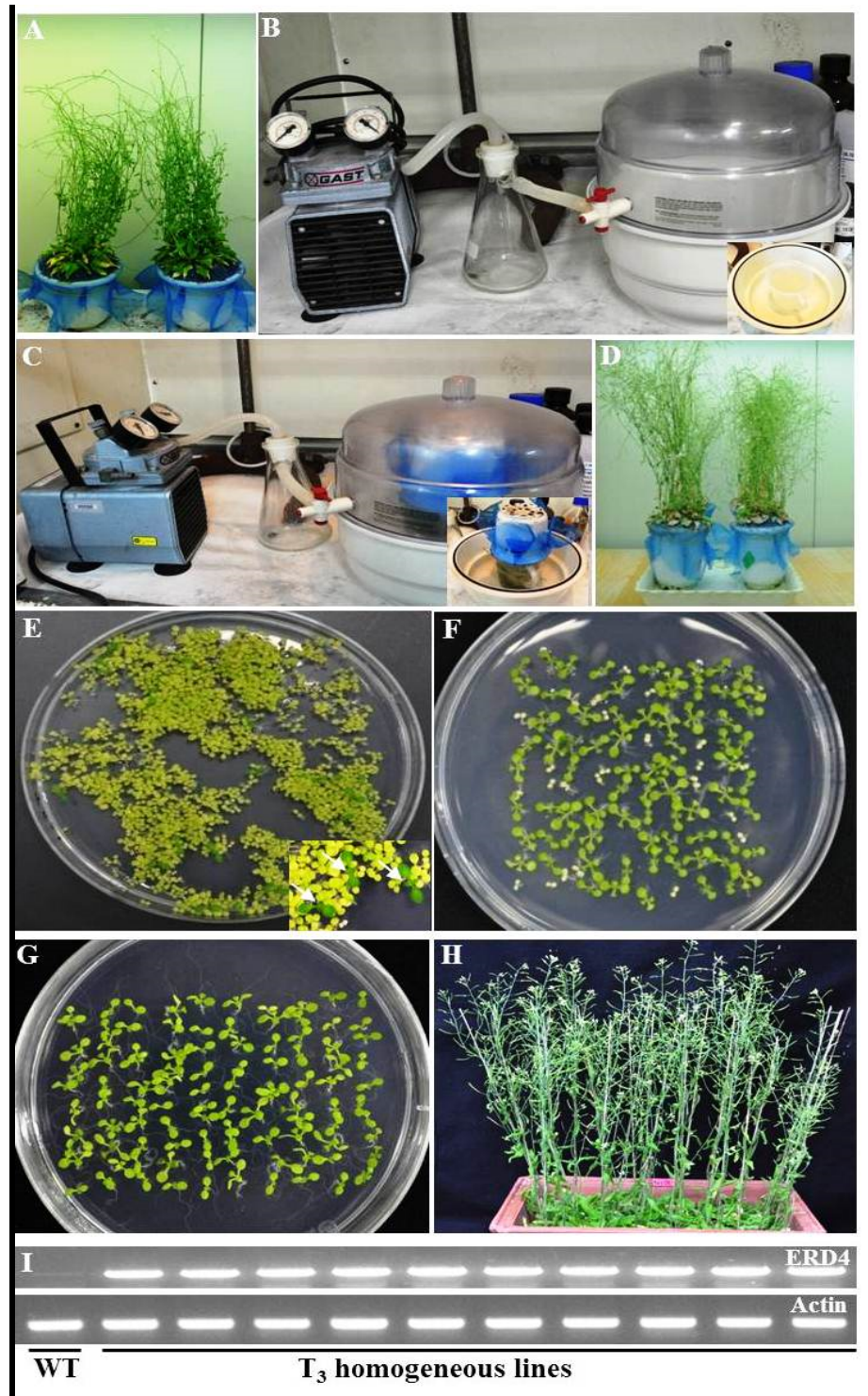

Fig. 2. Plant transformation and homogeneous line selection. The ERD4 gene was introduced into Arabidopsis plants by Agrobacterium-mediated vacuum infiltration method (A to D). Homo lines were selected on MS medium containing kanamycin (E to H). The expression of ERD4 gene in the transgenic lines was confirmed by RT-PCR (I). Arrows in (E) indicate seedlings that harbor the pBI121 vector and survive on kanamycin-containing medium. 


\section{CONCLUSION}

Using coffee genome information and molecular biological approach, we identified and cloned a coffee gene, and successfully introduced the coffee gene into Arabidopsis. All experimental steps are well-established and can be executed without difficulty in any plant biotechnology laboratory in Vietnam. This approach and methodology can be utilized to study the functions of genes not only in coffee plants but also in other important crops.

Acknowledgment: The authors acknowledge financial support from by the grants from the Next-Generation BioGreen21 Program (PJ01103601), Rural Development Administration, Republic of Korea and from the Mid-career Researcher Program (2011-0017357) through the National Research Foundation of Korea grant funded by the Ministry of Education, Science and Technology, Republic of Korea.

\section{Ứng dụng phương pháp tạo dòng và chuyển gen vào Arabidopsis để nghiên cứu chức năng gen ERD4 trong bộ gen cây Cà Phê}

- Nguyễn Đình Sỹ

Viện Công nghệ Sinh học và Môi trường, Trường Đại học Tây Nguyên

- Hunseung Kang

Khoa Nông nghiệp và Khoa học Sự sống, Trường Đại học Quốc gia Chonnam

\section{TÓM TẮT}

Cây Cà phê là cây công nghiệp đóng vai trò rất quan trọng, trong đó Coffea arabica (Cà phê chè) và Coffea canephora (cà phê vối) là 2 giống cung cấp hạt chủ yếu trên toàn thế giới. Mặc dù nhu cầu tiêu thu cà phê ngày càng tăng, nhưng các nông trang đang phải đối mặt với nhiều vấn đề nhu biến đổi môi truờng và sâu bệnh. Phuoong pháp lai truyền thống tốn rất nhiều thời gian trong việc cải thiện giống. Ứng dụng công nghẹ sinh học để khám phá nhũng gen chức năng trong bộ gen Cà phê là rất cần thiết nhằm đẩy nhanh quy trình tạo giống mói với nhũng đặc điểm tốt nhu khả năng chống hạn, kháng sâu bệnh. Hiện nay nhiều nghiên cứu trên thế giới đã báo cáo chuyển thành công gen vào trục tiếp trong mô cây Cà phê nhung tỉ lệ thành công thấp và tốn nhiều thời gian để chọn lọc. Để vuoọt qua nhũng hạn chế nêu trên, nghiên cứu này trình bày phuoong pháp chuyển gen vào cây mô hình Arabidopsis thaliana nhằm khám phá chức năng của gen cà phê nhanh nhất, dễ thực hiện, it tốn kém và có thể thực hiện ở hầu hết các phòng thí nghiệm nghiên cưu thưc vật trong điều kiện hiện nay ở Việt Nam.

Tù khóa: Arabidopsis, Bộ gene Cà phê, chọn dòng, chuyển gen thực vật

\section{REFERENCE}

[1]. A.P. Davis, R. Govaerts, D.M. Bridson, P. Stoffelen, An annotated taxonomic conspectus of the genus Coffea (Rubiaceae). Botanical Journal of the Linnean Society, 152, 165-512 (2006).
[2]. ICO annual review, ISSN, 1473-3331 (2012-2013).

[3]. F.L. Partelli, H.D. Vieira, A.P. Viana, P. Batista-Santos, A.E. Leita o, J.C. Ramalho, Low temperature impact on photosynthetic

Trang 60 
parameters in coffee genotypes. Pesquisa Agropecua'ria Brasileira, 44, 1404-1415 (2009).

[4]. A. Charrier, J. Berthaud, Botanical classification of coffee. In: Clifford MN, Wilson KC (eds), Coffee: botany, biochemistry and production of beans and beverage, Croom Helm, London, Sydney, 13-47 (1985).

[5]. P. Lashermes, J. Cros, P. Marmey, A. Charrier, Use of random amplified DNA markers to analyze genetic variability and relationships of Coffea species, Genet. Res. Crop Evol., 40,91-99 (1993).

[6]. F.M. DaMatta, J.D.C. Ramalho, Impacts of drought and temperature stress on coffee physiology and production: A review. Brazilian J. Plant. Physiol., 18, 55-81 (2006).

[7]. A. Pallavicini, L. Del Terra, M.R. Sondahl, Transcriptomics of resistance response in Coffea arabica L, in Proceedings of the 20th International conference on coffee science (ASIC '04), Bangalore, India, 6667 (2004).

[8]. L.G.E. Vieira, A.C. Andrade, C. Colombo, Brazillian coffee genome project: an ESTbased genomic resource. Brazillian Journal of Plant Physiology, 18, 1, 95-108 (2006).

[9]. I. Privat, A. Bardil, A.B. Gomez, D. Severac, C. Dantec, I. Fuentes, L. Mueller, T. Joët, P. David, S. Foucrier, S. Dussert, T. Leroy, L. Journot, A.D. Kochko, C. Campa, M.C. Combes, P. Lashermes, Bertrand, The 'PUCE CAFE' Project: the First $15 \mathrm{~K}$ coffee microarray, a new tool for discovering candidate genes correlated to agronomic and quality traits, $B M C$ Genomics, 12, 5 (2011).

[10]. M.K. Mishra, A. Slater, Recent advances in the genetic transformation of coffee,
Biotechnology Research International, 580857 (2012).

[11]. F. Denoeud, L. Carretero-Paulet, A. Dereeper, G. Droc, R. Guyot, M. Pietrella, C. Zheng, A. Alberti, F. Anthony, G. Aprea, J. Aury, P. Bento, M. Bernard, S. Bocs, C. Campa, A. Cenci, M. Combes, D. Crouzillat, C. Da Silva, L. Daddiego, F.D. Bellis, S. Dussert, O. Garsmeur, T. Gayraud, V. Guignon, K. Jahn, V. Jamilloux, T. Joët, K. Labadie, T. Lan, J. Leclercq, M. Lepelley, T. Leroy, L.T. Li, P. Librado, L. Lopez, A. Muñoz, B. Noel, A. Pallavicini, G. Perrotta, V. Poncet, D. Pot, Priyono, M. Rigoreau, M. Rouard, J. Rozas, C. Tranchant-Dubreuil, R. VanBuren, Q. Zhang, A.C. Andrade, X. Argout, B. Bertrand, A.D. Kochko, G. Graziosi, R.J. Henry, Jayarama, R. Ming, C. Nagai, S. Rounsley, D. Sankoff, G. Giuliano, V.A. Albert, P. Wincker, P. Lashermes, The coffee genome provides insight into the convergent evolution of caffeine biosynthesis, Science, 345, 1181 (2014).

[12]. C.R. Barton, T.L. Adams, M.A. Zarowitz, Stable transformation of foreign DNA into Coffea arabica plants, in Proceedings of the 14th International Conference on Coffee Science (ASIC'91), San Francisco, Calif, USA, 460-464, (1991).

[13]. R.F. Da Silva, A. Men'endez-Yuff'a, Transient gene expression in secondary somatic embryos from coffee tissues electroporated with the genes GUS and BAR, Electronic Journal of Biotechnology, 6, 1, 29-35 (2003).

[14]. V. Kumar, K.V. Satyanarayana, A. Ramakrishna, A. Chandrashekar, G.A. Ravishankar, Evidence for localization of $N$-methyltransferase (MMT) of caffeine biosynthetic pathway in vacuolar surface of Coffea canephora endosperm elucidated 
through localization of GUS reporter gene driven by NMT promoter, Current Science, 93, 3, 383-386 (2007).

[15]. J. Van Boxtel, M. Berthouly, C. Carasco, M. Dufour, A. Eskes, Transient expression of beta-glucuronidase following biolistic delivery of foreign DNA into coffee tissues, Plant Cell Reports, 14, 12, 748752 (1995).

[16]. A.G. Rosillo, J.R. Acuna, A.L. Gaitan, M. de Pena, Optimised DNA delivery into Coffea arabica suspension culture cells by particle bombardment, Plant Cell, Tissue and Organ Culture, 74, 1, 45-49 (2003).

[17]. A.F. Ribas, A.K. Kobayashi, L.F.P. Pereira, L.G.E. Vieira, Genetic transformation of Coffea canephora by particle bombardment, Biologia Plantarum, 49, 4, 493-497 (2005).

[18]. A.M. Gatica-Arias, G. Arrieta-Espinoza, A.M.E. Esquivel, Plant regeneration via indirect somatic embryogenesis and optimisation of genetic transformation in Coffea arabica L. cvs. Caturra and Catua, Electronic Journal of Biotechnology, 11, 1, 1-11 (2008).

[19]. E.V.S. Albuquerque, W.G. Cunha, A.E.A.D. Barbosa, Transgenic coffee fruits from Coffea arabica genetically modified by bombardment, In Vitro Cellular \& Developmental Biology-Plant, 45, 5, 532-539 (2009).

[20]. T. Hatanaka, Y.E. Choi, T. Kusano, H. Sano, Transgenic plants of coffee Coffea canephora from embryogenic callus via Agrobacterium tumefaciens-mediated transformation, Plant Cell Reports, 19, 2, 106-110 (1999).

[21]. T. Leroy, A.M. Henry, M. Royer, Genetically modified coffee plants expressing the Bacillus thuringiensiscrylAc gene for resistance to leaf miner, Plant Cell Reports, 19, 4, 382389 (2000).

[22]. S. Ogita, M. Uefuji, H. Morimoto, H. Sano, Application of RNAi to confirm theobromine as the major intermediate for caffeine biosynthesis in coffee plants with potential for construction of decaffeinated varieties, Plant Molecular Biology, 54, 6, 931-941 (2004).

[23]. R.L.R. Canche-Moo, A. Ku-Gonzalez, Burgeff C, V.M. Loyola-Vargas, L.C. Rodriguez-Zapata, E. Casta no, Genetic transformation of Coffea canephora by vacuum infiltration, Plant Cell, Tissue and Organ Culture, 84, 3, 373-377 (2006).

[24]. V. Kumar, K.V. Sathyanarayana, S.I. Saarala, P. Giridhar, A. Chandrasekhar, G.A. Ravishankar, Post transcriptional gene silencing for down regulating caffeine biosynthesis in Coffea canephora P. ex Fr, in Proceedings of the $20^{\text {th }}$ International Conference on Coffee Science (ASIC '04), Bangalore, India, 769-774 (2004).

[25]. A.F. Ribas, A.K. Kobayashi, L.F.P. Pereira, L.G.E. Vieira, Production of herbicide-resistant coffee plants (Coffea canephora P.) via Agrobacterium tumefaciens-mediated transformation, Brazilian Archives of Biology and Technology, 49, 1, 11-19 (2006).

[26]. A. Arroyo-Herrera, A.K. Gonzalez, R.C. Moo, Expression of WUSCHEL in Coffea canephora causes ectopic morphogenesis and increases somatic embryogenesis, Plant Cell, Tissue and Organ Culture, 94, 2, 171-180 (2008).

[27]. A.F. Ribas, E. Dechamp, A. Champion, Agrobacterium mediated genetic transformation of Coffea arabica (L.) is greatly enhanced by using established embryogenic callus cultures, BMC Plant Biology, 11, 92, (2011).

\section{Trang 62}


[28]. M. Sugiyama, C. Matsuoka, T. Takagi, Transformation of Coffea with Agrobacterium rhizogenes, in Proceedings of the 16th International Conference on Coffee Science (ASIC '95), Kyoto, Japan, 853-859 (1995).

[29]. V. Kumar, K.V. Satyanarayana, S.S. Itty, Stable transformation and direct regeneration in Coffea canephora $\mathrm{P}$ ex. Fr. by Agrobacterium rhizogenes mediated transformation without hairy-root phenotype, Plant Cell Reports, 25, 3, 214222 (2006).

[30]. E. Alpizar, E. Dechamp, B. Bertrand, P. Lashermes, H. Etienne, Transgenic roots for functional genomics of coffee resistance genes to root-knot nematodes, in Proceedings of the 21st International Conference on Coffee Science (ASIC '06), Montpellier, France, 653-659 (2006).

[31]. E. Alpizar, E. Dechamp, S. Espeout, Efficient production of Agrobacterium rhizogenes-transformed roots and composite plants for studying gene expression in coffee roots, Plant Cell Reports, 25, 9, 959-967 (2006).

[32]. J. Sambrook, E.F. Fritsch, T. Maniatis, Molecular Cloning. A Laboratory Manual, 2nd edn. Cold Spring Harbor, NY: Cold Spring Harbor Laboratory Press (1989).

[33]. N. Bechtold, G. Pelletier, In planta Agrobacterium mediated transformation of adult Arabidopsis thaliana plants by vacuum infiltration, Methods Mol. Biol. 82, 259-266 (1998). 